\title{
Cities in late medieval Europe: the promise and the curse of modernity
}

\author{
MARC BOONE* \\ Department of History, University of Ghent, Sint-Pietersnieuwstraat 35, BE-9000 \\ Ghent, Belgium
}

\begin{abstract}
This article examines how modern historiography has developed quite differentiated views on the way medieval cities have given expression to renewal and to creativity. 'National' traditions have played a highly influential role in modifying the general views articulated in the major syntheses produced by scholars such as Max Weber and Henri Pirenne at the beginning of the twentieth century. An almost jubilant way of looking at the city as the hotbed of modernity gave room, in the decades after the Great War, to pessimism and a negative view on urbanity, before a more nuanced and positive view has been re-established after World War II and in the course of recent paradigmatic changes.
\end{abstract}

Echoing the many pessimistic predictions about the future arising from the frantic pace of urbanization throughout today's globe, the United Nations recently estimated that in 2008 the proportion of the global population living in urban areas had reached 50 per cent and further predicted that in 2030 six out of ten people on this earth will be city dwellers. Existing cities, the report continued, cannot absorb this influx of residents, and the ensuing crises will be particularly extreme in much of Africa and Asia, where governments are simply not equipped to address what will be

\footnotetext{
* Based on research made possible in the context of the federal (Belgian) research programme (IAP, phase VI, $\mathrm{n}^{\circ} 32$ ): see www.cityandsociety.be/. A first and quite preliminary version of this text was presented as part of the keynote lecture at the International Mediaeval Congress in Leeds (UK) on 9 July 2007. A German version of that text was published as M. Boone, 'Die Mittelalterliche Stadt. Vorzeichen von Modernität, Ort des kulturellen Transfers?', Pro civitate Austriae. Informationen zur Stadtgeschichtsforschung in Österreich, 13 (2008), 5-17. Subsequently, versions of the text were presented at conferences in Helsinki, International Urban History Workshop, 'Big cities in Europe: cities in space', organized by the Finnish Historical Society (2009), Brussels Royal Flemish Academy of Arts and Sciences of Belgium, Brussels (2009), and Lisbon 'A cidade medieval em debate', Universidade Nova de Lisboa (2011). I am grateful to my colleagues for their helpful remarks and questions on all these occasions. Martha C. Howell suggested most valuable corrections to this text, for which I am extremely grateful, and another American friend and colleague, Susie Sutch, corrected the English. Both have had a decisive impact on what the text finally became. I am also very grateful to the two anonymous reviewers who read the text for Urban History.
} 
overwhelming demands for housing, healthcare and employment. ${ }^{1}$ The gloomy predictions may very well be justified, but it is perhaps also useful to recall that this is not the first period of rapid urbanization in history and not the first to provoke fears of socio-political disorder, moral collapse and demographic disaster. Urban history may reflect these fears, but it still reflects as well the hopes that urbanization has inspired. And, for this reason, it may be useful to gain insight into how historiography presents these shifts in how generations of historians have looked upon the urban phenomenon and have considered it, at given moments and in a given context, to be also a token of progress and of modernization. In what follows, I shall focus on this ambivalent vision and how it is contingent upon the changing paradigms in history itself. Since most of the examples and models have been designed on the basis of urban experiments in medieval western Europe, I will refer to cities from that part of the world in the first place, though many visions that their experiences have underpinned were designed to be applied on a broader and more general scale.

While historians have long acknowledged these cities' importance in western European history, for they were the nodes of the commercial revolution that gave birth to the modern market economy, they have not consistently been interested in urbanity itself - what it meant to live in cities, why people so ardently sought to live as urban citizens and what rights and privileges attended their status. ${ }^{2}$ The uneven history of their explorations reveals a great deal about the ideological underpinnings of much of our historiography, and the principal purpose of this article is to investigate the ways that the lives of historians themselves and the history of our profession have had a lot to do with the way scholars have told - or not told - the story of urbanity in this age.

This historiography is in many respects a reflection of bourgeois values and bourgeois ascendancy, and to enshrine it as the full story of Europe's urbanization is to write out the many horrors that attended the rush to cities in this or any other period of history, western or global, including our own age. At the same time, however, we would be unwise to dismiss either the history of medieval cities or the historiography that has given us the stories we have about them. For all our nostalgia about country values and rural pleasures, after all, westerners today choose to live in cities, and

1 The report World Urbanization Prospects. The 2007 Revision. Highlights was published by the United Nations' Department of Economic and Social Affairs, Population Division, available through: www.un.org/esa/population/publications/wup2007/ 2007WUP_Highlights_web.pdf. The cited first key finding of the 2007 revision is on p. 16.

2 The bibliography on European urban history has become very large. Two recent surveys include J.-L. Pinol (ed.), Histoire de l'Europe Urbaine, 2 vols. (Paris, 2003), and P. Clark, European Cities and Towns, 400-2000 (Oxford, 2009), with a short historiographic survey and bibliography. See also a series of (often nationally organized) specialized journals, in addition to this journal: Histoire urbaine (France), Stadsgeschiedenis (Belgium and the Netherlands), Città e Storia (Italy) with specific bibliographies. 
they have been making that choice for centuries, ever since that epoch over a half a millennium ago when people first made commercial cities powerful actors in European politics. By 1500, just after the first wave of European urbanization that allows for quantification, one can posit that about 15 per cent of the population in western Europe lived in cities. This number hides important 'regional' differences, for at the same moment the two most urbanized parts of Europe, northern and central Italy and the southern Netherlands, were up to 30 per cent urbanized, a proportion that as always needs to be put in context and to be critically examined regarding the standards used. ${ }^{3}$ By 1800, the global figure for European urbanization had risen to about 21 per cent, but with industrialization the pace of urbanization increased dramatically so that already by 1910 just over 50 per cent of Europeans were urbanites. ${ }^{4}$

My claim is certainly not that the late medieval city was simply an early version of western cities today, nor is it that they should serve as direct models for urban policy-making today. Some of the fears that medieval cities inspired amongst the secular and ecclesiastical powers of the day, and many of the attractions that drew people to cities in the later Middle Ages, are at work today. ${ }^{5}$ That conflicted history of repulsion and attraction ineluctably returns us to historiography itself, where the city has alternately been portrayed as the hotbed of the evils associated with modernity, on the one hand, and on the other as the crucible where modernity gave birth to extraordinary innovation and creativity.

\section{Historians' ambivalence}

Like history itself, historians' accounts of European urbanization have been an unstable mix of light and dark - celebration on the one hand, condemnation or suspicion on the other. This alteration reveals a great deal not just about our historiographical traditions but also about the history that gave rise to these traditions. Historians of the late nineteenth century saw medieval urbanization in a largely positive light, as the seedbed of modernity, and they understood modernity to mean a specific form of 'democracy', embodied by the driving and creative bourgeois forces of society. This understanding of urbanity was closely tied to the professionalization of history writing, the emergence of what is still called

${ }^{3}$ See the remarks by G. Chittolini, 'Urban population, urban territories, small towns: some problems of the history of urbanization in northern and central Italy (thirteenth-sixteenth centuries)', in P.C.M. Hoppenbrouwers, A. Janse and R. Stein (eds.), Power and Persuasion. Essays on the Art of State Building in Honour of W.P. Blockmans (Turnhout, 2010), 233-7.

${ }^{4}$ Clark, European Cities, 128 and 229. Quantitative data are treated and collected in the classic work by J. De Vries, European Urbanization 1500-1800 (London, 1984).

5 This is the important central statement in a collection of essays concerning the urban history of the Low Countries (an English version is forthcoming with Taylor and Francis, London): L. Lucassen and W. Willems (eds.), Waarom mensen in de stad willen wonen, 1200-2010 (Amsterdam, 2009) (contributions on the Middle Ages by M. Boone and W. Blockmans). 
'scientific' history writing in Europe. ${ }^{6}$ What is particularly interesting here is that it was in the advanced industrialized and urbanized parts of Europe, limited at that period to western Europe, that what Peter Clark has characterized as a 'town history' with a 'boosterism' quality took root. In these texts, industrial and commercial advancement, communal cultural life and public resources, civic pride and civic identity were celebrated. In short, cities were beacons of modernity. And modernity was almost without blemish. ${ }^{7}$

It is no wonder that one of the leading historians of that generation, indeed one of the greatest historians of medieval urbanity, was the Belgian Henri Pirenne (1862-1935). The son of a successful entrepreneur in textiles in the booming industrial town of Verviers and a firm believer in progress and liberal politics in the context of the nineteenth-century nation-state, he became the incarnation of renewed urban history and the voice of a generation of historians. ${ }^{8}$ The history of the recently constructed Belgian nation-state (Belgium came into existence only in 1830 after having split from the united Netherlands), eager to justify its existence alongside 'big' European powers such as France and Germany, was to become Pirenne's best-known work: his Histoire de Belgique. Pirenne's personal 'openness to innovation, the key sign of modernism' made him, to cite further the qualification of Pyenson and Verbruggen, 'an apostle of modernism', just as the nation, whose history he so successfully described in a publication that made his reputation as a first-ranking scientist in the eyes of the

${ }^{6}$ See the remarks referring to several 'national' traditions in works such as M. Bentley, Modern Historiography. An Introduction (London and New York, 2003); G. Lingelbach, Klio macht Karriere. Die Institutionalisierung der Geschichtswissenschaft in Frankreich und der USA in der zweiten Hälfte des 19. Jahrhunderts (Göttingen, 2003); B. Melman, The Culture of History. English Uses of the Past 1800-1953 (Oxford, 2006); C. Delacroix, F. Dosse and P. Garcia, Les courants historiques en France, XIXe-Xxe siècle, 2nd edn (Paris, 2005).

7 P. Clark, 'The city', in P. Burke (ed.), History and Historians in the Twentieth Century (Oxford, 2002), 38. As for the notion of modernity, see the all-encompassing definition by A. Giddens, Conversations with Anthony Giddens: Making Sense of Modernity (Stanford, 1998), 94: 'a shorthand term for modern society, or industrial civilization. Portrayed in more detail, it is associated with (1) a certain set of attitudes towards the world, the idea of the world as open to transformation, by human intervention; (2) a complex of economic institutions, especially industrial production and a market economy; (3) a certain range of political institutions, including the nation-state and mass democracy. Largely as a result of these characteristics, modernity is vastly more dynamic than any previous type of social order. It is a society - more technically, a complex of institutions - which, unlike any preceding culture, lives in the future, rather than the past.'

8 The classic biography of Pirenne remains of course B. Lyon, Henri Pirenne. A Biographical and Intellectual Study (Ghent, 1974). An important biographical note was written by Pirenne's most influential student F.L. Ganshof, Henri Pirenne, in Biographie Nationale, 30 (1958), electronically available at http://digitheque.ulb.ac.be/fr/digitheque-henripirenne/biographie/la-vie/index.html. A recent version by W. Prevenier, Pirenne, Jean Henri Otto Lucien Marie, in Nationaal Biografisch Woordenboek, 19 (2009), cols. 753-70. A not so traditional and rather atypical appraisal of Pirenne as an urban and economic historian, reading as a kind of anti-Lyon, is the short but brilliant text of J. Mundy, 'Henry Pirenne: a European historian', Journal of European Economic History, 6 (1977), 473-80. See also S. Keymeulen and J. Tollebeek, Henri Pirenne, Historian: A Life in Pictures (Leuven, 2011). 
bourgeoisie, incarnated modernity. ${ }^{9}$ At the end of the nineteenth century, the same nation was, indeed, one of the strongest industrialized nations and hence a successful illustration of the collective energy unleashed by the bourgeois and capitalist spirit. ${ }^{10}$ It was evident to Pirenne that such a story belonged to cities and that the history of urbanity in Europe had ineluctably led to this moment. Pirenne's fascination with cities began early in his professional life, with his Ph.D. thesis of 1883. Describing the constitution of the medieval town of Dinant, a city along the Meuse, he set the tone: 'J'ai cherché à faire, pour une ville belge, ce qui a été fait, pendant les dernières années, pour tant de villes allemandes et françaises. ${ }^{11}$

Although known primarily as a social and economic historian, Pirenne was also an institutional historian, as Jan Dhondt perspicuously pointed out in a 1966 article entitled 'Henri Pirenne: historien des institutions urbaines'. ${ }^{12}$ In fact, a careful reading of Pirenne locates him as a predecessor to many of the scholars associated with the new Institutional Economics, and it is those studies rather than Pirenne's more famous Mohammed and Charlemagne that have best stood the test of time. Pirenne was also a beneficiary of the then dominant tradition of positivist and historicist scholarship, which emphasized careful analysis of sources, respect for 'facts' retrievable from them alone and the technical skill needed to extract that information. History was thus professionalized as a 'science', just as was announced by the banner behind which Gabriel Monod, the director of the influential Revue historique, marched in 1883 during the funeral of the

${ }^{9}$ L. Pyenson and C. Verbruggen, 'Elements of the modernist creed in Henri Pirenne and George Sarton', History of Science, 49 (2011), 377-94.

10 A recent reappraisal of the fundamental period of Belgian history in E. Witte, G. KurganVan Hentenryk and E. Lamberts et al., Nation et démocratie 1890-1921. Actes du colloque international Bruxelles, 8-9 juin 2006 (Brussels, 2007), passim, and G. Deneckere, Les turbulences de la Belle Epoque 1878-1905 (Brussels, 2005).

11 'I tried to do for a Belgian city what has already been undertaken during the recent years for so many German and French cities', published in 1889 as Histoire de la constitution de la ville de Dinant au Moyen Âge in the series of monographs of the faculty of Letters of Ghent University where Pirenne had been appointed three years earlier in 1886 as professor of medieval history.

12 J. Dhondt, 'Henri Pirenne: historien des institutions urbaines', Annali della fondazione italiana per la storia amministrativa, 3 (1966)), 81-129 (reprinted in the collection of Dhondt's essays: Hommes et pouvoirs. Les principales études de Jan Dhondt sur l'histoire du 19e et 20e siècles (Ghent, 1976), 63-119, with a critical introduction by Wim Blockmans). The article's first chapter opens with a remarkable sentence which deliberately seems to recall the style of Pirenne, or tries to make a pastiche: 'Henri Pirenne possédait une capacité incomparable à projeter son message dans les esprits individuels de ceux qui l'approchaient comme dans celui des ensembles intellectuels qui l'entendaient. Ce fut bien certainement son atout principal. Que l'on y joigne une intelligence véritablement somptueuse et le non-conformisme scientifique, caractéristique "sine qua non" du grand savant' ('Pirenne disposed of an almost incomparable capacity to inculcate his message in the hearts and minds of those who dealt with him, or of the intellectual groups he addressed. Without questioning this was one of his most important gifts. One should add to that a remarkable intelligence and a scientific non-conformism, the ultimate characteristic of any great scholar'): Hommes et pouvoirs, 65 . 
French radical republican Gambetta: 'l'histoire est la science maîtresse'. ${ }^{13}$ That approach was evident even in Pirenne's early articles on urban constitutions, which appeared in 1893-98 in the same journal. These studies in urban history culminated in his 1910 Les anciennes démocraties des PaysBas. ${ }^{14}$ If we now return to these studies, we are struck by how successfully the extent to which Pirenne was able to combine and bridge the best elements of the dominant schools of history writing of the day, the French and German. Pirenne had received part of his training in both Paris and Berlin (and Leipzig) and was very much aware that he was writing the history of what he called 'le point sensible de l'Europe' where the Germanic and Latin parts of the continent met and merged. ${ }^{15}$ In the second phase of his career during the Great War, which broke out just when he had acquired international recognition, he would discover, however, just how 'sensitive' a place this was. ${ }^{16}$ Despite that unhappy future, Pirenne's scholarship combined, as did none other, the best elements of both traditions and helped bridge stubborn divides between socio-economic, institutional and cultural history. This combination gave Pirenne an almost holistic view of the positive effects of an urbanity that combined peculiarly urban institutions with the creative powers of generations of merchants and highly skilled artisans in the two most urbanized parts of Europe: northern and central Italy on the one hand, the Low Countries on the other. ${ }^{17}$ At the centre of these histories were studies of communal organizations, guilds, confraternities, all of which were thought to express a set of values and a sense of collectivity that had almost religious inspiration. Pirenne's interpretations, although perhaps most clearly summarized in his Anciennes démocraties, reached their widest audience in the little book he published after his grand tour in the United States in 1923, Medieval Cities: Their Origins and the Revival of Trade. Acclaimed as a classic from the start, it is still read in university classrooms throughout the English-speaking world. ${ }^{18}$

${ }^{13}$ On the journal (first issue published in 1876) and Monod: Delacroix, Dosse and Garcia, Les courants historiques en France, 117-25.

14 The first translation in English, bearing the wrong, but given the specific circumstances of World War I understandable, title: Belgian democracy (Manchester, 1915), was afterwards repeatedly re-edited under the more correct title Early Democracies in the Low Countries. Urban Society and Political Conflict in the Middle Ages and the Renaissance (New York, 1963).

15 J. Tollebeek, "“Au point sensible de l'Europe": Huizinga et Pirenne', Revue Belge de Philologie et d'Histoire, 74 (1996), 429 (re-edited in his De ekster en de kooi. Nieuwe opstellen over geschiedschrijving (Amsterdam, 1996), 243).

16 A testimony to the success and renown of Pirenne before the Great War is the booklet edited on the occasion of the birth of the Foundation Pirenne when he was honoured for 25 years of teaching in Ghent: Manifestation en l'honneur du m. le professeur Henri Pirenne. Bruxelles, 12 mai 1912 (Mons, 1912).

17 The comparison introduced by Pirenne continues to provoke historical questionnaires and research. For a recent evaluation of the question: E. Crouzet-Pavan and E. LecuppreDesjardin (eds.), Villes de Flandre et d'Italie (XIIIe-XVIe siècle). Les enseignements d'une comparaison (Turnhout, 2008)

18 The first English edition appeared in Princeton in 1925 - it is still a widely read book at American colleges. The French edition was published in 1927, immediately hailed by 


\section{Collapse of a paradigm}

Yet after the Great War, it was impossible to sustain the optimism about cities and the modernity they represented. For Pirenne, as for almost all of his contemporaries, there were no more intellectual certainties. Just like the medieval monuments that were destroyed in the course of the war the great drapery hall of Ypres, the old university library of Louvain, the cathedral of Reims - celebratory histories of cities were in ruin. Historical scholarship itself seemed illusory; it was 'the end of a great illusion' as the Italian medievalist Cinzio Violante has put it in describing the state of mind of Pirenne and his fellow historians after 11 November 1918. ${ }^{19}$ Scepticism about society's foundations and especially about 'progress' and modernity was now the rule, doubt also about history's capacity to trace clearly any such development and thus to serve as a guide in making choices about the future. Urban history itself seemed beside the point, for it could no longer serve as the laboratory for studying progressive modernity. Speaking particularly of British historiography, Peter Clark has emphasized that it was not only that the German tradition, which had once so profoundly influenced the study of urbanity, was unpopular and unfashionable after 1918, but also that the aversion to urban history was intensified by what he characterized as a 'growing trend against cities in British culture'. ${ }^{20}$ The decades after 1918 thus saw an outpouring of publications and research on rural history; in this wave of nostalgia of the 1930s, scholars emphasized the culture of the countryside, a place of supposed simplicity and purity that had been almost destroyed in the trenches of World War I. Although we do not yet have similarly detailed studies of this trend in Belgian and German historiography, there is no doubt that there too rural history displaced to a large extent urban history. It was only in certain places like the Scandinavian countries that had kept out of World War I that urban history prospered..$^{21}$ In Germany,

Lucien Febvre, one of the founders of the Annales (see infra), in the following words 'Un de ses livres comme seuls sont capables d'en produire les hommes qui, ayant excellé toute leur vie dans une profession, ont par surcroît le don d'animer ce qu'ils touchent. Il est signé Henri Pirenne' ('One of the books written by an author who has dominated all his life his profession and who has been given the quality to breath life into all they touch upon'): L. Febvre, Vivre l'histoire (ed. Brigitte Mazon) (Paris, 2009), 306.

19 This feeling is clearly brought to our attention in C. Violante, La fine della 'grande illusione'. Uno storico europeo tra guerra e dopoguerra, Henri Pirenne (1914-1923). Per una rilettura della 'Histoire de l'Europe' (Bologna, 1997); a review of this book by P. Toubert, 'Henri Pirenne et l'Allemagne (1914-1923)', Le Moyen Âge, 107 (2001), 317-20. More recently, a German version was published containing an important introduction on Violante by Giorgio Cracco: C. Violante, Das Ende der 'grossen Illusion'. Ein europäischer Historiker im Spannungsfeld von Krieg und Nachkriegszeit, Henri Pirenne (1914-1923) - Zu einer Neulesung der 'Geschichte Europas' (Berlin, 2004)

${ }^{20}$ Clark, 'The city', 40-1.

${ }^{21}$ For Belgium, see C. Billen and M. Boone, 'L'histoire urbaine en Belgique', Città e Storia, 5 (2010), 3-22. In Germany, the paradigm change occurring after World War I led to a reappraisal of the ideas already formulated in the second unzeitgemässe Betrachtung (untimely meditations) by Friedrich Nietzsche, published in 1874 'Vom Nutzen und 
the much acclaimed book by Oswald Spengler on the fall of western civilization voicing the intellectual despair during the Weimar Republic situated twentieth-century Germany in the winter phase of human history, characterized by 'tendencies of an irreligious and unmetaphysical urban cosmopolitanism'. ${ }^{22}$

Rescue came indirectly, in the form of the French Annales school. ${ }^{23}$ The Annales did not in the first place attach the same importance to urban history as had been the case in the preceding period of historicism, when books such as the classic handbook, even bible, of historicism, the Introduction aux sciences historiques of Charles Seignobos and Charles-Victor Langlois (1863), dominated. ${ }^{24}$ Both Marc Bloch and Lucien Febvre, the founders of the Annales, had been at the front during the Great War, and both invested much scholarly energy, Bloch in particular, in rural history. ${ }^{25}$ Gradually, however, the emphasis that Annalists put on economic and structural elements provoked a renewed interest also in urban phenomena - the urban economy, the effects of commercialization on social relations and the meaning of city space - all recalling the kind of history Pirenne had written (who, not incidentally, had originally been asked to head up the Annales). It was, however, the so-called second generation of the Annales, under the direction of Fernand Braudel, that made a clear 'urban turn'. It began with regional studies such as Pierre Goubert's seminal book on the city and countryside of Beauvais in the early modern period (1960), which became a model for this approach. By then, the combination of rapidly accelerating urbanization in France and the intellectual exhaustion of rural studies put towns again on the (historical) research agenda. That Braudel himself was also significantly influenced by Pirenne and knew his

Nachteil der Historie für das Leben' (On the use and abuse of history for life): see O.G. Oexle, 'Staat - Kultur - Volk. Deutsche Mittelalterhistoriker auf der Suche nach der historischen Wirklichkeit, 1918-1945', in P. Moraw and R. Schieffer (eds.), Die deutschsprachige Mediävistik im 20. Jahrhundert (Ostfildern, 2005), 72-4. For the remarks concerning Scandinavia, see the discussion following the presentation of parts of this text at Helsinki in April 2009 (see n. *).

22 Cited and put into the intellectual context of Weimar Germany in R.J. Evans, The Coming of the Third Reich (London, 2004), 121. The citation from Spengler: O. Spengler, Der Untergang des Abendlandes: Umrisse einer Morphologie der Weltgeschichte. I: Gestalt und Wirklichkeit (Vienna, 1918), 73-5.

${ }^{23}$ Named after the French review founded in 1929 for which not surprisingly its two famous founders, Marc Bloch and Lucien Febvre, had in vain tried to have Pirenne accept to act as its first president, see Delacroix, Dosse and Garcia, Les courants historiques en France, 200-95; on the link between Pirenne and Bloch and Febvre: B. Lyon, The Birth of Annales History: The Letters of Lucien Febvre and Marc Bloch to Henri Pirenne (1921-1935) (Brussels, 1991). An Anglo-Saxon view on the Annales school is offered by T. Stoianovitch, French Historical Method: The Annales Paradigm (Ithaca, 1976).

${ }^{24}$ On this bible of historicism: Delacroix, Dosse and Garcia, Les courants historiques en France, 145-53.

${ }^{25}$ See, in the abundant literature on Bloch, how this interest was developed during the close contacts with British colleagues whose interest in agrarian history as we have seen following Clark's analysis (see n. 2) had taken over in the post-war period: Fr.-O. Touati, Marc Bloch et l'Angleterre (Paris, 2007). On Bloch: O. Dumoulin, Marc Bloch (Paris, 2000). 
work very well also helps explain the Annalists' (tardy) 'urban turn'. ${ }^{26}$ In his Civilisation matérielle of 1967 (the first of the three-part series), Braudel thus described the essential function of cities: 'Pas de ville sans marché et pas de marchés régionaux ou nationaux sans villes ... Enfin, pas de villes sans pouvoir à la fois protecteur et coercitif. ${ }^{27}$ In other words: no city without market and no city without the power both to protect and to coerce. Pirenne could easily have written this sentence.

There were other moves in a similar direction, most notably among the Chicago school of urban sociology. In the years after the Great War and led by Robert Park (1864-1944) and colleagues, these scholars offered a analytical model for the study of cities from a socio-spatial perspective, thus pioneering an urban ethnography of social behaviour that focused less on classes and groups than on interactive behaviour among individuals and groups. Their interests lay in the affective dimensions of communities undergoing the abrupt transition from local place to urban grid: 'The city is a state of mind, a body of customs and traditions, and of organized attitudes and sentiments that inhere in this tradition. ${ }^{28}$ Their approach was first registered among British historians in the work of men like Asa Briggs and H.J. Dyos, but in the decades since has left its mark on all research on urban history, including medieval urban history. ${ }^{29}$

\section{The Germans: absent, then present}

The Germans, once at the centre of western historiography and chief architects of nineteenth-century urban historiography, were, however, largely absent from these developments, isolated in traditions constipated by attacks on Rankean method and later contaminated by Nazism and its uses of historiography. European historical scholarship in the Pirenne tradition, once a brilliant merger of the French and German traditions, was now coming apart, and urban historiography suffered as a result.

The important German tradition reached back well into the middle of the nineteenth century. Focusing on the legal, political and economic institutions and on the constitutional authority that took root in the urban world, with works by historians Otto von Gierke (1841-1921), Gustav von Schmoller (1836-1917) and Karl Lamprecht (1856-1915) and by sociologist Ferdinand Tönnies (1855-1936), the Germanic tradition reached its apogee

${ }^{26}$ See the abundant proof in one of the few reliable studies on Braudel so far: P. Daix, Braudel (Paris, 1995), 91-5, 273. After having heard a lecture in Algiers on 29 Jan. 1931 by Pirenne on his Mahomet and Charlemagne thesis, Braudel went so far as to adapt the subject of his own thesis, putting forward the Mediterranean instead of Philip II of Spain.

27 F. Braudel, Civilisation matérielle, économie et capitalisme, Xve-XVIIIe siècle. Tome 1: les structures du quotidien: le possible et l'impossible, 2nd edn (Paris, 1979), 423.

${ }^{28}$ R. Park (with R.D. MacKenzie and E. Burgess), The City: Suggestions for the Study of Human Nature in the Urban Environment (Chicago, 1925). On the Chicago school: K. Plummer (ed.), The Chicago School: Critical Assessments, 4 vols. (London, 1997).

29 Clark, 'The city', 42-3. 
in the years before and shortly after World War I. ${ }^{30}$ Lamprecht in particular had personally and profoundly influenced Pirenne, but their relationship would come to a dramatic halt during World War I when Lamprecht endorsed the 'Aufruf an die Kulturwelt', an apology for the German aggression against Belgium in 1914. ${ }^{31}$ Lamprecht even came to Brussels in 1915 in order to convince his Belgian friends that it was Belgium's destiny to be part of a new German Empire. ${ }^{32}$ But he came in vain: he did not even succeed in meeting Pirenne in person and got no closer than the office of Guillaume Des Marez, a direct student of Pirenne and by that period professor at the Free University of Brussels and city archivist. ${ }^{33}$ The breach with the German tradition was a matter of intellectual divergence but also, and given the personal histories involved, a deeply felt event for people like Pirenne, Bloch and others who had suffered as a result of World War I. ${ }^{34}$

On the German side, however, there were several different historiographic voices. The cultural science (Kulturwissenschaft) of Max Weber (1864-1920), and Georg Simmel (1858-1918), was fundamentally different from the cultural history (Kulturgeschichte) of Karl Lamprecht,

${ }^{30}$ See the entries and reference to further literature on Gierke and Schmoller by Rüdiger vom Bruch in R. vom Bruch and R. A. Müller (eds.), Historikerlexikon von der Antike bis zur Gegenwart, 2nd edn (Munich, 2002), 108-9, 279-80. On Tönnies, see references on the website of the Tönnies Gesellschaft: www.ftg-kiel.de/; his complete works are edited by Walter De Gruyter (Berlin and New York), first vol. 1998.

31 On Lamprecht, see the entry by Louise Schorn-Schütte in Historikerlexikon, 189. With regard to the 'Methodenstreit', the 12 volumes of his Deutsche Geschichte triggered from 1891 on: G. Oestreich, 'Die Fachhistorie und die Anfänge der sozialgeschichtliche Forschung in Deutschland', Historische Zeitschrift , 208 (1969), 320-63; R. Vom Bruch, Wissenschaft, Politik und öffentliche Meinung. Gelehrtenpolitik im wilhelmischen Deutschland (1890-1914) (Husum, 1980). Lutz Raphael, 'Historikerkontroversen im Spannungsfeld zwischen Berufshabitus, Fächerkonkurrenz und sozialen Bedeutungsmustern. Lamprecht-Streit und französicher Methodenstreit der Jahrhundertwende in vergleichender Perspektive', Historische Zeitschrift, 251 (1990), 325-63. Concerning his relation to Pirenne, see, apart from Lyon's biography of Pirenne, the following source editions: B. Lyon, 'The letters of Henri Pirenne to Karl Lamprecht', Bulletin de la Commission Royale d'Histoire, 132 (1966), 161-231, to be completed by H. Van Werveke, 'Karl Lamprecht et Henri Pirenne', Bulletin de la Commission Royale d'Histoire, 138 (1972), 39-60, and M. Boone, "“L'automne du Moyen Âge": Johan Huizinga et Henri Pirenne ou "plusieurs vérités pour la même chose"', in P. Moreno and G. Palumbo (eds.), Autour du XVe siècle. Journées d'étude en l'honneur d'Alberto Varvaro. Communications présentées au Symposium de clôture de la chaire Francqui au titre étranger (Liège, 10-11 mai 2004) (Geneva, 2008), 36-7.

32 B. Lyon, 'The war of 1914 and Henri Pirenne's revision of his methodology', in J. Tollebeek, G. Verbeeck and T. Verschaffel (eds.), De lectuur van het verleden. Opstellen over de geschiedenis van de geschiedschrijving aangeboden aan Reginald de Schryver (Leuven, 1998), 511-12.

33 B. Lyon, 'Guillaume Des Marez and Henri Pirenne: a remarkable rapport', Revue Belge de philologie et d'histoire, 77 (1999), 1068-9; on Des Marez: C. Billen and M. Boone, 'Pirenne in Brussels before 1930. Guillaume Des Marez and the relationship between a master and his student', Belgisch tijdschrift voor nieuwste geschiedenis. Revue belge d'histoire contemporaine, 41 (2011), 459-85.

34 Bloch served the full years of the war as a soldier in the French army, on different fronts; Pirenne lost one of his sons in the war, was imprisoned because of his resistance to the German cultural and educational policies imposed on the occupied part of Belgium; see the already cited biographies of both men. 
which was positivist, developmental and finally nationalist, its nationalist bias becoming quite clear when Lamprecht acted as one of the 93 subscribers who signed the 'Aufruf an die Kulturwelt' on 4 October $1914 .{ }^{35}$

Max Weber was probably the most influential representative of the German tradition, and it was his version of medieval urban history that would dominate after the crises of both world wars. Like Pirenne, he argued that the western city, born in the central and late Middle Ages, was identified not only by its market functions, but also by its corporative capacity to produce and execute its own laws. In effect the medieval coniuratio, which Weber understood to be an expression of what he called a herrschaftsfremde Charisma, was essentially a form of emotional community based on a mutual contract. In this, Weber owed much to Otto von Gierke's notion of free unity (Freie Einung), but he drew his prime examples from the Italian commune in its most classical form, which dated from the thirteenth century, the period of the so-called popular regimes. ${ }^{36}$ His posthumously published and unfinished book Die Stadt (the city), drawn from the writings he had left in the journal Archiv für Sozialwissenschaft und Sozialpolitik under the title Die Stadt. Eine soziologische Untersuchung, made the argument crystal clear: the western city was simultaneously a defensive organization, a market, the independent generator of law and justice, and the possessor of rights to self-government. ${ }^{37}$ Weber's ideas about the city were not always well understood, however, and his arguments are sometimes misrepresented in contemporary scholarly literature. ${ }^{38}$

Not surprisingly, in the immediate aftermath of the Great War and during the Weimar period - not to mention the period of fascism historical research was manipulated and subjected to ideological agendas

35 On this manifesto: Jürgen and Wolfgang von Ungern-Sternberg, Der Aufruf 'An die Kulturwelt!' Das Manifest der 93 und die Anfänge der deutschen Kriegspropaganda im Ersten Weltkrieg (Stuttgart, 1996), passim.

36 A recent reappraisal of German historiography and of Weber's position concerning urban history is to be found in F.G. Hirschmann, Die Stadt im Mittelalter (Munich, 2009), 62-3. On the Italian communes of the so-called 'popular type': J.-Cl. Maire Vigueur, Cavaliers et citoyens. Guerre, conflits et société dans l'Italie communale XIIe-XIIIe siècles (Paris, 2003), and J.-Cl. Maire Vigueur and E. Faini, Il sistema politica dei comuni italiani (secoli XII-XIV) (Milan and Turin, 2010), passim.

37 Kl. Schreiner, 'Die mittelalterliche Stadt in Webers Analyse und die Deutung des okzidentalen Rationalismus. Typus, Legitimität, Kulturbedeutung', in J. Kocka (ed.), Max Weber, der Historiker (Göttingen, 1986), 119-50; G. Dilcher, 'Max Webers Stadt und die historische Stadtforschung der Mediëvistik', Historische Zeitschrift, 267 (1998), 91-125; more recent with abundant references to an equally abundant literature on Weber and his theories: B. Scheller, 'Das herrschaftsfremde Charisma der Coniuratio und seine Veralltäglichungen. Idealtypische Entwicklungspfade der mittelalterlichen Stadtverfassung in Max Webers "Stadt"', Historische Zeitschrift, 281 (2005), 307-36. For Weber's text, see the relevant sections of his Wirtschaft und Gesellschaft, most conveniently in M. Weber, The City (Glencoe, IL, 1958) (part of Wirtschaft und Gesellschaft; critical edn: Wirtschaft und Gesellschaft: Grundriss der verstehenden Soziologie (Cologne, 1956)).

38 Lexikon des Mittelalters adds to a sense of confusion and even contradiction as is convincingly argued in G. Dilcher, 'Einheit und Vielheit in Geschichte und Begriff der Europäischen Stadt', in P. Johanek and F.-J. Post (eds.), Vielerlei Städte. Der Stadtbegriff (Cologne, Weimar and Vienna, 2004) 20-1. 
that violated the terms both of older historicism and Ranke's positivism as well as 'scientific' history writing more generally and Weber's form of historical sociology. ${ }^{39}$ In their place came an approach propagated by Stefan George and his followers, who provided a reductive reading of a great philosophical tradition reaching back to Nietzsche, which had argued that history was best considered a guide for the Volksgemeinschaft, the people's community - and that the job of historians was to provide lessons from the past, useful for both the present and future. ${ }^{40}$ While Stefan George may have worked hard to make a revival of a 'secret and eternal Germany' reminiscent of the imperial grandeur of the past, and may even have contributed to undermine the Weimar Republic, his spiritual endorsement of the new nationalist movement of Hitler did not mean he engaged himself at the latter's side. For one thing: he never allowed himself to become a member of a nazified cultural organization. Since he died in 1933, he did not have to witness the reality of the new regime that had come to power in the same year. ${ }^{41}$ In the cultural climate imposed on Germany in the years following the coming to power of the Nazis in 1933, history, and so too urban history, did not have to make claims to truth in either a Rankean or in Weberian sense; it had to be a servant of 'life'. Hence, although Weber had distanced himself from Rankean positivism and historicism, his effort to replace that paradigm with a more holistic and cultural approach fell before this powerful criticism that, born of political ambition and a dominant ideological frame, easily trumped both Rankean historicism and the 'objectivity' it promised as well as Weberian abstractions. ${ }^{42}$

In both Weimar and Nazi Germany, the anti-urbanism of historical scholarship was, in effect, a version of anti-modernity which in itself implied hostility to all things urban. ${ }^{43}$ The result was a clear shift towards Landesgeschichte and agrarian and territorial history, an approach that

${ }^{39}$ See several contributions to Moraw and Schieffer (eds.), Die deutschsprachiche Mediävistiek im 20. Jahrhundert; O.G. Oexle, L'historisme en débat. De Nietzsche à Kantorowicz (Paris, 2001) (translation of his Geschichtswissenschaft im Zeichen des Historismus (Göttingen, 1996)), passim; and O.G. Oexle, 'Das Mittelalter und das Unbehagen an der Moderne. Mittelalterbeschwörungen in der Weimarer Republik und danach', in S. Burghartz, H.J. Gilomen, G. Marchal, R.C. Schwinges and K. Simon-Muscheid (eds.), Spannungen und Widersprüche. Gedenkschrift für Frantisek Graus (Sigmaringen, 1992), 125-53.

40 See the fundamental discussion in Oexle, 'Staat - Kultur - Volk', 73 and 75, where he takes the very influential book by Kantorowicz (1895-1973) on Frederik II as the example for this evolution. The same Kantorowicz in his address at the Historikertag in Halle (Grenze, Möglichkeiten und Aufgaben der Darstellung mittelalterlicher Geschichte) had formulated the programme of the group around Stefan George. Note that for this 'creative' use of his philosophy Nietzsche himself cannot be held responsible. See in general: M. Zapata Galindo, Triumph des Willens zur Macht. Zur Nietzsche-Rezeption im NS-Staat (Hamburg, 1995).

41 Evans, The Coming of the Third Reich, 411-12.

42 See the analysis by O.G. Oexle, "Vom "Staat" zur "Kultur" des Mittelalters. Problemgeschichten und Paradigmenwechsel in der deutschen Mittelalterforschung', in N. Fryde, P. Monnet, O.G. Oexle and L. Zygner (eds.), Die Deutung des mittelalterlichen Gesellschaft in der Moderne (Göttingen, 2004), 40-7.

43 An overview of the reappraisal of the notion Volksgemeinschaft in German historiography: H. Mommsen, 'Changing historical perspectives on the Nazi dictatorship', European 
would prove useful in laying claims to European territory. ${ }^{44}$ Historians would thus easily be lost in what has been labelled the 'Night and Mist' (Nacht und Nebel) of the Nazi party. Already by the late 1920s, the Rhine had become a Schicksalsstrom (river of fortune); on its left bank, in France, was the Nouvelle Histoire of the Annales scholars with its interest in individuals, groups and their mental and social constructs, while on the German right bank the dominant tone in historical research was linked with notions such as Volk and Gemeinschaft - with their pernicious subtext of race and blood. ${ }^{45}$ In reaction, after World War II and the Nazi period, there seemed to be a return to an ideal of Rankean objectivity and the explicit rejection of the idea that historical scholarship had direct relevance for contemporary society and politics. As in Ranke's day, historians returned to the study of the state and political history understood as the recitation (or recovery) of facts. The kind of history associated with Marc Bloch and the Annalists found few adherents. ${ }^{46}$ That Bloch had been murdered by the Nazis surely had something to do with this, but, as we have seen, urban history was late to be put on the agenda by the Annalists as well. Clearly, however, the Germans would have done well to ask what they could learn from their French colleagues. ${ }^{47}$

Urban history thus seemed to have no direct future in Germany and only in France under Braudel's generation of Annalists did there seem to be stirrings of new interest in urbanity. But it was in Western Germany, not France, that urban history, particularly medieval urban history, found new life, a life going back, directly or indirectly, to Weber and to another great German tradition, that of the history of law. In this particular respect, the work of Hans Planitz (1882-1954) Die deutsche Stadt im Mittelalter (dating from 1954) needs to be mentioned. ${ }^{48}$ Planitz belonged to a tradition of legal historians who, in Germany and abroad, have dominated more specifically the research agendas concerning both the character and the

Review, 17 (2009), 76-9. For the historiographic debate during and after the Nazi period: O.G. Oexle, 'Von der völkischen Geschichte zur modernen Sozialgeschichte', in H. Duchhardt and G. May (eds.), Geschichtswissenschaft um 1950 (Mainz, 2002), 1-36.

44 Oexle, 'Staat - Kultur - Volk', 92-4, and M. Werner, 'Zwischen politischer Begrenzung und methodischer Offenheit. Wege und Stationen deutscher Landesgeschichtsforschung im 20. Jahrhundert', in Moraw and Schieffer (eds.), Die deutschsprachige Mediävistiek im 20.

45 The image of the Rhine's two banks is taken from Oexle, 'Staat - Kultur - Volk', 96-7, who borrows it from Ulrich Raulff, the reputed biographer of Marc Bloch.

46 Ibid., $100-1$.

47 The question was posed in a provocative way, recalling the fierce attack on German historiography and science in general by Henri Pirenne in one of his public addresses as rector of Ghent University in 1922 'Ce que nous devons désapprendre de l'Allemagne' by O.G. Oexle, 'Was deutsche Mediävisten an der französischen Mittelalterforschung interessieren muss', in M. Borgolte (ed.), Mittelalterforschung nach der Wende 1989 (Munich, 1995), 89-127.

${ }^{48}$ H. Planitz, Die deutsche Stadt im Mittelalter. Von der Römerzeit bis zu den Zunftkämpfen (Graz and Cologne, 1954). 
origins of urban constitutions. ${ }^{49}$ The general move in Germany is, however, best represented by Edith Ennen (1907-99), professor in Bonn. Although trained in the tradition of Landesgeschichte and a student of Franz Steinbach (1895-1964), she made her name internationally with Die Frühgeschichte der europäischen Stadt (1953). Gradually - very gradually - Weber's ideas found new life in what was beginning to be called Städtegeschichte (urban history), although at the still active Institut fur vergleichende Städtegeschichte (Institute for Comparative Urban History) at the University of Münster, founded in 1969 by Heinz Stoob (1919-97), a student of Hermann Aubin (1885-1969), the initial approach was neo-Rankean. ${ }^{50}$ In keeping with that tradition's emphasis on fact gathering, objectivity and neutrality, the Institute produced urban atlases and the like. Although hardly useless exercises in a nation where most cities had been reduced to rubble and traces of the medieval past buried, the work nevertheless lacked interpretative power. ${ }^{51}$ Ennen's book of 1953 was a follow-up to her Die europäische Stadt des Mittelalters als Forschungsaufgabe unserer Zeit (The European medieval city as research programme for our time) which had first appeared in 1941 but was subsequently re-issued in several editions. There, Ennen had first distanced herself from the Landesgeschichte that until 1945 had been conceived as a tool for the present and brutally put into service by the Nazis, under Franz Petri's (1903-93) Westforschung programme. Like both Aubin and Steinbach (both Ennen and Stoob were their students), Petri belonged to the war generation and had been at the front in World War I; their revisionist views made them hostile to Pirenne and his school. ${ }^{52}$ During the occupation of Belgium the Nazis imposed this programme on Belgian universities. ${ }^{53}$ Pirenne, long the bête noire of the

49 See the fundamental overview by P. Johanek, 'Stadtgeschichtsforschung - ein halbes Jahrhundert nach Ennen und Planitz', in F. Opll and Ch. Sonnlechner (eds.), Europäische Städte im Mittelalter (Innsbruck and Vienna, 2010), 49-50.

50 Werner, 'Zwischen politischer Begrenzung und methodischer Offenheit', 336. On the founding of this institute, in the context of German historiography: Hirschmann, Die Stadt im Mittelalter, 70.

${ }^{51}$ See the essay by one of the former directors of the Munsterian institute Peter Johanek, ' $\mathrm{Zu}$ neuen Ufer? Beobachtungen eines Zeitgenossen zur deutschen Mediävistik von 1975 bis heute', in Moraw and Schieffer (eds.), Die deutschsprachige Mediävistiek im 20. Jahrhundert, 168-9, with references to the atlases published so far.

52 A short but penetrating assessment of their role in World War II: B.-A. Rusinek, “"Westforschungs"-Traditionen nach 1945. Ein Versuch über Kontinuität', in B. Dietz, H. Gabel and U. Tiedau (eds.), Griff nach dem Westen. Die 'Westforschung' der völkisch-nationalen Wissenschaften zum nordwesteuropäischen Raum (1919-1960), 2 vols. (Münster and New York, 2003), vol. II, 1150-1.

53 This was particularly the case in the University of Ghent, looked upon as an outpost of Germanic culture in the West since it was 'germanized' in the sense that the Dutch language was imposed as the language in which teaching was done in 1930, a development which pushed Pirenne to leave Ghent for Brussels. Franz Steinbach appointed during the first winter semester of the occupation in 1940-41 to teach in Ghent noted however in an official report to the military command in Belgium that Pirenne still was revered in Ghent and that a vast majority of both professors and students were supporters of Belgium and rather hostile to 'völkische' points of view. One student he quoted told him that 'scientific truth has no Vaterland (home country)': see M. Nikolay-Panter, 'Geschichte, Methode, Politik. 
Westforschung, would have turned in his grave. ${ }^{54}$ The Westforschung project was devoted to the study of the border regions west of the Rhine, a project intending to offer historical and geographical insight that would legitimate a revision of the peace (Diktat) of Versailles that had been 'imposed' on Germany at the end of World War I. ${ }^{55}$

Of course, German historians did not all embrace the crude categories of Nazi ideology that easily; many of them and certainly the representatives of the older generation continued to consider history as an apolitical subject, meaning essentially it was not tied to party politics. The professional organization of the historian's guild, however, was subject to a deliberate attempt to nazification. ${ }^{56}$

But Ennen's book, whatever its murky origins in a tradition of highly politicized scholarship were, left a wake, inspiring a new body of work on the medieval city as a political body that uniquely combined individual rights with collective values. Cities in this mode were considered to have generated cultural interaction by facilitating the sharing of social space and thereby to have produced and protected artistic and socio-political experimentation. City dwellers were, in effect, 'forced to be free', and came to understand that their freedom was bequeathed by the community and won in community struggle. This insight was most prominently brought forward in yet another great tradition which after World War II revived in the former German Democratic Republic. It is probably not a complete

Das Institut und die geschichtliche Landeskunde der Rheinlande, 1920-1945', in Dietz, Gabel and Tiedau (eds.), Griff nach dem Westen, vol. II, 713.

54 Petri published his thesis on the linguistic border in Belgium and the Germanic elements in Wallonia and northern France in 1937. This thesis, so many sources confirm, had an important personal influence on Hitler who adapted his policy towards Belgium and the Netherlands after reading it (after the war, as many German university professors, Petri was easily at work again after a short period of denazification, became professor at Münster between 1951 and 1961, and returned afterwards to Bonn). In his Nazi period, he had criticized Pirenne abundantly (his review of the last part of Pirenne's Histoire de Belgique numbered 110 pages!) and was co-responsible for the remarkable 'translation' of Pirenne's great posthumous book, his Mahomet et Charlemagne of 1937, a translation falsified in a way to glorify the Germanic influence in early medieval Europe; see P. Schöttler, 'Henri Pirenne, historien européen, entre la France et l'Allemagne', Revue belge de philologie et d'histoire, 76 (1998), 877-8. On Petri: K. Ditt, 'Die Kulturraumforschung zwisschen Wissenschaft und Politik. Das Beispiel Franz Petri (1903-1993)', Westfälische Forschungen, 46 (1996), 73-176, and the more critical assessment of Westforschung by the Dutch sociologist H. Derks, Deutsche Westforschung. Ideologie und Praxis im 20. Jahrhundert (Leipzig, 2001), passim, who develops a more critical stance towards the work and activities of Petri. The same author added new elements not very favourable to Petri's role to the dossier in 2005: H. Derks, 'German Westforschung, 1918 to the present. The case of Franz Petri, 1903-1993', in I. Haar and M. Fahlbusch (eds.), German Scholars and Ethnic Cleansing 1919-1945 (New York, 2005), 175-99.

55 Fundamental research concerning these activities is presented by P. Schöttler, 'Die historische Westforschung zwischen "Abwerhkampf" und territorialer Offensive', in idem (ed.), Geschichtschreibung als Legitimationswissenschaft 1918-1945 (Frankfurt, 1997), 204-61. See also the (impressive) collection of essays: Dietz, Gabel and Tiedau (eds.), Griff nach dem Westen; two essays concern Franz Petri: the one by Martina Pitz and one by Karl Ditt.

56 Though 'this made little difference in reality: the profession was already extremely hierarchical': R.J. Evans, The Third Reich in Power, 1933-1939 (London, 2006), 312-13. 
surprise that the man who was responsible for the continuation of a certain view on urban history in the former DDR or Eastern Germany, though he himself never became a member of the communist party, was directly linked to Henri Pirenne. Heinrich Sproemberg (1889-1966) had indeed been formed in the great German tradition of among others Gustav Schmoller, and belonged personally to the liberal tradition of the Berliner bourgeoisie. ${ }^{57}$ When he came to intellectual maturity, however, he saw his chances of an academic career thwarted, first because of his critical stance towards the military and political logic of Wilhelmine Germany, afterwards in the course of the Weimar Republic and during the Nazi period, for reasons of intellectual jealousy and racial prejudices, since he was partially of Jewish descent. He recalled this hesitant start in the profession in one of his last works, an autobiographical sketch in which he put his intellectual relationship to Henri Pirenne at the centre. Sproemberg had indeed written abundantly on subjects related to Belgian and Flemish history and in doing so had first established intellectual contacts with Pirenne in the months before World War I had started. Both men would continue a mainly epistolary relationship till very shortly before Pirenne's death in $1935 .{ }^{58}$ Sproemberg, condemned to an existence in the margins of historical research till the end of the Nazi regime and the establishment of the German Democratic Republic, kept the bonds with Pirenne and with Marc Bloch and the French Annales historians alive, however. ${ }^{59}$ His own scientific activities promoted first the study of religiously inspired social movements, and second in importance the study of the commercial organization of the German Hanse. Both were important items with direct links to urban history, though of course the latter was so in a much more explicit way. The Eastern German link to urban history evident in both Pirenne and Weber and in the study of societal modernism was advanced in several works, all of them inspired by Sproemberg or by his students' scientific activity. This influence is clearly discernible in works by Erika Engelmann on the communal movement and by Evamaria Engel on the 'German city in the Middle Ages' ${ }^{60}$ In a very bland mode, even after the German reunification after the fall of the Berlin Wall in 1989, Engel acknowledged Marxist inspiration, referring to Marx's interpretation of medieval communal movements, an interpretation which he in turn had based on the analysis already made by the French historian Augustin Thierry (1795-1856). ${ }^{61}$ Therefore both in Western and in Eastern German

57 See M. Borgolte, Sozialgeschichte des Mittelalters. Eine Forschungsbilanz nach der deutschen Einheit (Munich, 1996), 9-19.

58 See the unfinished and postumously published chapter 'Pirenne und die Deutsche Geschichtswissenschaft' in H. Sproemberg, Mittelalter und demokratische Geschichtsschreibung. Ausgewählte Abhandlungen (ed. M. Unger) (Berlin, 1971), 377-446.

59 Borgolte, Sozialgeschichte des Mittelalters, 12.

60 Ibid., 278-89, the references to both seminal books: E. Engelmann, Zur städtischen Volksbewegung in Südfrankreich: Kommunefreiheit und Gesselschaft, Arles 1200-1250 (Berlin, 1959), and E. Engel, Die deutsche Stadt des Mittelalters (Munich, 1993).

61 Borgolte, Sozialgeschichte des Mittelalters, 280-1. 
historiography, bridges were constructed to overcome the many gaps ahead: the conceptual one between Marxist and liberal historiography, the temporary one separating actual research from the great tradition of Max Weber and his predecessors, von Gierke, Schmoller and the like. ${ }^{62}$

In a recent survey of German medieval research, Otto Gerard Oexle concludes that historians now agree that medieval society was as much a 'communal' society as a 'feudal' society. His prime examples - and there could be many more - were taken from the work of Gerhard Dilcher (who has also written extensively on Max Weber) and Eberhard Isenmann. ${ }^{63}$ Both scholars emphasize the importance of brotherhood-like organizations in urban society: in the organization of burghers, of artisans, of religious and economic organizations, in the maintenance and inculcation of peace and control of behaviour. ${ }^{64}$ Peter Blickle, inspired both by Weber and the Lamprecht tradition of the late nineteenth century, has pleaded for years, not least in a European ESF programme concerning the coming about of the modern state, that the notion of Kommunalismus, one of the key notions (he uses the word Elefantenbegriffe), captures the ethic of medieval society just as much as do other concepts like feudality, parliamentarianism and so on. ${ }^{65}$

Of course, Blickle not only refers to urban movements when he speaks of communal movements, but the city played a fundamental role in the development of this concept. It is also important to understand that this principle cannot be extended to all European medieval cities, for they did not all meet this standard. Both Pirenne and Weber took cities of the southern Low Countries and northern/central Italy as their examples and tended to extend the model far beyond these boundaries. These were the two poles of what urban historians and geographers used to call the 'blue banana' - the urban belt stretching in the form of a banana over Europe, linking south-eastern England, the Low Countries, the Rhineland, western Switzerland to northern Italy. While hardly representative of all medieval cities, it is nevertheless true that they were centres of artistic

62 On the intellectual evolution and gradual unification (though of course important intellectual and ideological divides remained in place): Borgolte, Sozialgeschichte des Mittelalters, 287-312, and a direct testimony by E. Engel, 'Bürgertum - Bürgerkampf - Bürgerstadt. Probleme beim Versuch einer Synthese deutscher Stadtgeschichte des Mittelalters', in M. Borgholte (ed.), Mittelalterforschung nach der Wende 1989 (Munich, 1995), 407-25.

63 Oexle, "Vom "Staat" zur "Kultur" des Mittelalters', 57-8. Oexle refers to Gerhard Dilcher, 'Die Rechtsgeschichte der Stadt', in K.S. Bader and G. Dilcher, Deutsche Rechtsgeschichte. Land und Stadt - Bürger und Bauer im Alten Europa (Berlin, Heidelberg and New York, 1999), $249-827$.

${ }^{64}$ E. Isenmann, 'Gesetzgebung und Gesetzgebungsrecht in spätmittelalterlichen Deutscher Städte', Zeitschrift für historische Forschung, 28 (2001), 1-94 and 161-261. In his synthesis Die deutsche Stadt im Spätmittelalter (1250-1500) (Stuttgart, 1988), Isenmann makes his the characteristics Max Weber used to qualify the medieval city.

65 P. Blickle, Kommunalismus: Skizzen einer gesellschaftlichen Organisationsform, 2 vols. (Oldenbourg, 2000); see the collection of essays in the context of the ESF (European Science Foundation) programme: P. Blickle, Resistance, Representation and Community (Oxford, 1997). 
accomplishment and economic energy of such a scale as to produce a cultural pattern that others sought to emulate. ${ }^{66}$

Knut Schulz's synthesis of scholarship regarding the twelfth- and thirteenth-century communal movement in this so-called blue banana makes exactly this point and brings us close to the present. His too-often ignored book 'Denn sie lieben die Freiheit so sehr' ('They loved liberty so much' perhaps not a title apt to attract the right audience) was published in 1992. ${ }^{67}$ A year earlier, the University of Leipzig had founded a 'KarlLamprecht Gesellschaft' - a significant move in a nation that had recently been unified and perhaps a signal of the return of an historiographic tradition that had been abandoned for almost a century. ${ }^{68}$

\section{The new historiography in historical context}

As we enter the second decade of the twenty-first century, we perhaps have sufficient distance to assess these developments, now 20 to 30 years, even more, in the making. Seen from this perspective, the historiography just reviewed has led scholars to take up, anew, questions concerning the relationship between individual rights and political organization at the level of the city, region and state alike. Contemporary political developments surely helped fuel the interest - the collapse of the eastwest divide and the end of the 'cold war', which had dominated European history since World War II, along with the discussions around the enlargement and institutional deepening of the European Union. These changes may be considered a European variant of larger processes involving globalization, the emergence of a modern communication society and the consequently ever more rapid mobility of people, things, ideas and diseases - the very issues that so concerned policy-makers at the United Nations when they warned of the dangers attending global urbanization today. For historians, an associated question is the following: are we prepared to keep the nineteenth-century nation-state as our frame of reference, or should we take much more seriously the different levels

66 The effects of comparisons and of differences between these two highly urbanized regions of medieval Europe were different for each of them: see the contributions (on the demographic aspects and on comparisons) by G. Pinto, P. Stabel and W. Blockmans in Crouzet-Pavan and Lecuppre-Desjardin (eds.), Villes de Flandre et d'Italie (XIIIe-XVIe siècle). I developed some of these aspects further in M. Boone, A la recherche d'une modernité civique. La société urbaine des anciens Pays-Bas au bas Moyen Âge (Brussels, 2010), 109-21.

${ }^{67}$ Knut Schulz, 'Denn sie lieben die Freiheit so sehr...' Kommunale Aufstände und Entstehung des europäischen Bürgertums im Hochmittelalter (Darmstadt, 1992). On the importance of this work see the remarks concerning its place in a re-evaluation of the communal movement by Dilcher, 'Einheit und Vielheit in Geschichte und Begriff', 21.

68 See the websites: www.lamprecht-gesellschaft.de/ and http://www.eniugh.org/ the latter of the European Network in Universal and Global History of which the Lamprecht Gesellschaft is part. In 1993, a collection of essays in which Leipzig-based historians sought to renew their link to Lamprecht was published: G. Diesener (ed.), Karl Lamprecht weiterdenken. Universal- und Kulturgeschichte heute (Leipzig, 1993). 
at which community, individual rights and duties and political order are constituted?

The recent work on medieval urban history discussed in this article can help with this question. As Knut Schulz commented in the introduction to his overview of the different twelfth-century communal movements, the old discussion of whether medieval society was really 'democratic' is irrelevant. Rather, four issues should govern our study of these societies: the spatial organization of political activity and of public debate; how rule was legitimated; what duties and rights attended self-government; and individual rights and liberties. The first issue, that of the 'public' and 'space', recalls Jürgen Habermas' Öffentlichkeit, a concept that has inspired work across fields and chronology. ${ }^{69}$ Habermas of course spoke of another age and did not intend 'space' in quite the same material way as it is intended in studies of medieval cities. ${ }^{70}$ Research ever since has made the medieval city one of the loci where such a political space was prominent. ${ }^{71}$ Yet, another recent survey of medieval social history, this one focused on England, makes a similar argument. In discussing the question of whether the Middle Ages knew an 'individual' in the sense traditionally thought to have been produced during the Renaissance by a cultural process of 'self-fashioning', Miri Rubin argues that in late medieval society (and I would emphasize 'urban' society) growing individualism interlocked with participation in collective communal endeavours. ${ }^{72}$ Similarly, Richard Britnell, in his discussion of economic life in Britain's comparatively modest urban settings (London is of course the exception), stresses that a commercial mentality necessarily produced or at least combined with a sense of collectivity because decisions about commerce had to be taken by the group as a whole even if individuals were to reap their separate rewards. ${ }^{73}$ Herman Pleij's studies of Dutch vernacular literature in the late Middle Ages exposed the same issues: individual rights and freedoms

${ }^{69}$ See the references referring to Sigrid Weigel, 'On the "topographical" turn: concepts of space in cultural studies and Kulturwissenschaften. A cartographic feud', European Review, 17 (2009), 187-201.

${ }^{70}$ J. Habermas, Strukturwandel der Öffentlichkeit. Untersuchungen zu einer Kategorie der bürgerlichen Gesellschaft (Neuwied and Berlin, 1962), 16-21, rejects the possibility of defining the existence of a public political space for the late Middle Ages and early modern period, reflecting in doing so the historical knowledge of the period in which he conceived his ideas (the early 1960s).

${ }^{71}$ See among others the collections of essays concerning different parts of Europe, which all were published in a remarkably short span of time thus testifying to a historiographic impulse: U. Kundert, B. Schmid and R. Schmid (eds.), Ausmessen - Darstellen - Inszenieren. Raumkonzepte und die Wiedergabe von Räumen in Mittelalter und frühen Neuzeit (Zürich, 2007); P. Boucheron and O. Mattéoni (eds.), Les espaces sociaux de l'Italie urbaine (XIIe-XVe siècles). Receuil d'articles (Paris, 2005); C. Deligne and C. Billen (eds.), Voisinages, coexistences, appropriations. Groupes sociaux et territoires urbains (Moyen Âge-16e siècle) (Turnhout, 2007); P. Monnet, Villes d'Allemagne au Moyen Âge (Paris, 2004).

72 M. Rubin, 'Identities', in R. Horrox and W. M. Ormrod (eds.), A Social History of England, 1200-1500 (Cambridge, 2006), 402ff.

73 R. Britnell, 'Town life', in Horrox and Ormrod (eds.), Social History of England, 163-8. 
were achieved - and understood to have been achieved - in collective action. ${ }^{74}$

Thus, historians of the medieval city and of medieval culture more generally may be on to something. In a multitude of ways, the medieval commune was indeed an experiment in communal living, an effort to reconcile individual and collective needs. Schulz is also right: the question of whether these cities were 'democratic' is what the French call a 'faux problème', or yet another manifestation of a too simple Whig view of history, since in most parts of Europe centralized states made the dream of urban independence just a dream or, as was the case in Italy, most of the communes evolved into city-states dominated by a small group of elite families, eventually giving way to a 'signoria' under the princely authority of one family. The Italian example, in fact, gives the lie to the overly optimistic views of Robert Putnam's Making Democracy Work regarding the resilience of the medieval ideal. ${ }^{75}$ Nevertheless, the medieval communes succeeded in launching a set of social and legal constructs which in the long run did have a fundamental influence in the search for an equilibrium between private interest and the commonwealth, the bonum commune. ${ }^{76}$ As Aaron Gourevitch observed in his classic book on medieval culture, the fundamental input of medieval urbanity was a crucial one: the type of the 'burgher', member of a free and independent urban community. However highly developed on the cultural level the cities of both the Byzantine and Islamic world may have been, they failed to develop this social type, the basis for further social and economic developments that help to explain the European Sonderweg. ${ }^{77}$ But more than the set of rules and texts, however important they may have been for further developments, the coming about of the first real Republic on Europe's soil ('the fear of some, the envy of others and the wonder of all their neighbours' as the famous quote from Sir William Temple in 1673 goes), the Dutch Republic, cannot be explained without referring to the centuries-old accumulation of urban ideology and political practices in the medieval communes of the southern Low Countries where so much began. ${ }^{78}$

${ }^{74}$ See the life-long research by Herman Pleij, synthesized in his recent magisterial contribution to a new general history of Dutch literature: $\mathrm{H}$. Pleij, Het gevleugelde word. Geschiedenis van de Nederlandse literatuur, 1400-1560 (Amsterdam, 2007).

75 R.D. Putnam, R. Leonardi and R. Nannetti, Making Democracy Work: Civic Traditions in Modern Italy (Princeton, 1993); an important critique (among many others): N. Terpstra, 'Republics by contract. Civil society, social capital and the Putnam thesis in the papal state', Storicamente, 2 (2006) (see: www.storicamente.org) .

${ }^{76}$ See the collection of essays on the 'bonum commune' as an ideological tool developed and discussed in late medieval cities in E. Lecuppre-Desjardin and A.-L. Van Bruaene (eds.), De Bono communi. The Discourse and Practice of the Common Good in the European city $\left(13^{\text {th }}-16^{\text {th }}\right.$ c.) (Turnhout, 2010).

77 A. Gourevitch, Les catégories de la culture médiévale (Paris, 1983), 210-11. Albeit originally dating from 1972, his text has become widely known since its translation into French and the preface by Georges Duby from 1983.

78 See M. Boone and M. Prak, 'Rulers, patricians and burghers: the great and the little traditions of urban revolt in the Low Countries', in K. Davids and J. Lucassen (eds.), 
Although, as I hope to have demonstrated, the history of the medieval city has been consistently informed by the ideological predilections of its historians, it may nevertheless be worthwhile to return to the debates put on the agenda by preceding generations, by Pirenne, Weber and so many others. Urban history and urban studies are indeed booming in many respects: the number of new reviews and research programmes that focus on the city and the success of individual conferences bear witness to that energy. Reorienting history towards what distinguished it as urban offers a possible way out of the stalemate and suffocating specialization that historical research seemed to be heading towards in recent times. Historians and students of urban society have begun to understand that the medieval city was, if not the birthplace of 'democratic modernity' in the celebratory mode of nineteenth-century historiography, an experiment in social organization that produced a unique partnership between the individual and the collective. It will do well to consider what made that happen, made it work and made it fail, when thinking about the present.

In his famous Apologie pour l'histoire ou le métier d'historien (1941-42) Marc Bloch recalls a 1928 visit with Henri Pirenne to Stockholm following an international congress held in Oslo. Both men had just arrived, and Pirenne asked 'Qu'allons-nous voir d'abord? Il paraît qu'il y a un hôtel de ville tout neuf. Commençons par lui' (What will we see first? It seems that they have a brand new city hall here. Let's start by visiting that). And Bloch adds that Pirenne seemed to want to prevent him from asking a question by adding 'Si j'étais antiquaire, je n'aurai d'yeux que pour les vieilles choses. Mais je suis un historien. C'est pourquoi j'aime la vie' (If I were an antique dealer I would be interested in old things, but I'm an historian, that's why I love life in all its diversity). ${ }^{79} \mathrm{~A}$ lesson, perhaps, for historians today as they contemplate our urban past.

A Miracle Mirrored. The Dutch Republic in European Perspective (Cambridge, 1995), 99-134, and M. Boone, 'The Dutch Revolt and the medieval tradition of urban dissent', Journal of Early Modern History, 11 (2007), 351-75.

${ }^{79}$ Marc Bloch, L'histoire, la guerre, la résistance, ed. Annette Becker and Etienne Bloch (Paris, 2006), 879 . 